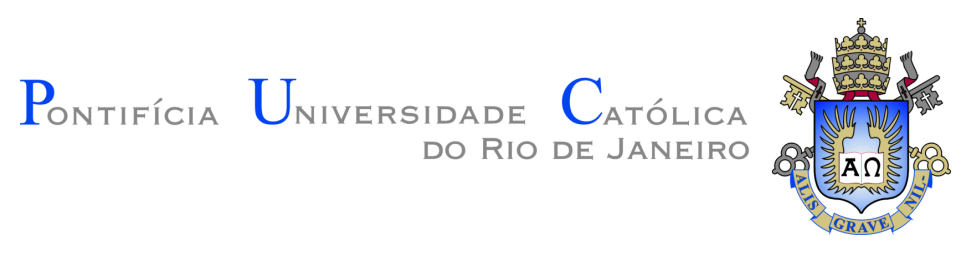

Paulo Rodrigo Capeleti

\title{
Macroprudential Policies at Work: How do Government-Owned Banks affect Credit \\ Markets?
}

\author{
Dissertação de Mestrado
}

Thesis presented to the Programa de Pós-graduação em Economia da PUC-Rio in partial fulfillment of the requirements for the degree of Mestre em Economia .

Advisor : Prof. Márcio Gomes Pinto Garcia

Co-advisor: $\quad$ Prof. Fábio Miessi Sanches 
Paulo Rodrigo Capeleti

\section{Macroprudential Policies at Work: How do Government-Owned Banks affect Credit \\ Markets?}

Thesis presented to the Programa de Pós-graduação em Economia da PUC-Rio in partial fulfillment of the requirements for the degree of Mestre em Economia. Approved by the undersigned Examination Committee.

Prof. Márcio Gomes Pinto Garcia

Advisor

Departamento de Economia - PUC-Rio

Prof. Fábio Miessi Sanches

Co-advisor

Departamento de Economia - PUC-Rio

Prof. Leonardo Bandeira Rezende

Departamento de Economia - PUC-Rio

Prof. Klênio de Souza Barbosa

Departamento de Economia - Insper

Prof. Augusto Cesar Pinheiro da Silva

Vice Dean of the Centro de Ciências Sociais - PUC-Rio 
All rights reserved.

\section{Paulo Rodrigo Capeleti}

B.A., Economics, Universidade de São Paulo (USP), 2014.

Bibliographic data

Capeleti, Paulo R.

Macroprudential Policies at Work: How do GovernmentOwned Banks affect Credit Markets? / Paulo Rodrigo Capeleti; advisor: Márcio Gomes Pinto Garcia; co-advisor: Fábio Miessi Sanches. - Rio de janeiro: PUC-Rio , Departamento de Economia, 2018.

v., 44 f: il. color. ; $30 \mathrm{~cm}$

Dissertação (mestrado) - Pontifícia Universidade Católica do Rio de Janeiro, Departamento de Economia.

Inclui bibliografia

1. Economia - Teses. 2. Spread Bancário;. 3. Competição Bancária;. 4. Crédito Público e Privado;. I. Garcia, Márcio. II. Miessi, Fábio. III. Pontifícia Universidade Católica do Rio de Janeiro. Departamento de Economia. IV. Título.

CDD: 330 


\section{Acknowledgments}

First of all, I want to thank my family, Suzi, Paulo, Sandra, Juliana, Ana Clara, Diego and Beto, who have always been by my side and encouraged me to follow my life goals.

I thank my advisor and co-advisor, Márcio and Fábio. Your knowledge, effort and guidance were essential in order to get this work done and I will always be thankful for that.

I am also grateful for having worked with Márcio as a research assistant for almost a year. Everything I learned with you, be it technical or not, is priceless.

I cannot forget to thank Leo, who also helped me to put the train on the rails at the beginning of this journey.

To the friends I've made during these two years, I could not even quote names, you are the best people I could be with to face this challenge. 


\section{Abstract}

Capeleti, Paulo R.; Garcia, Márcio (Advisor); Miessi, Fábio (CoAdvisor). Macroprudential Policies at Work: How do Government-Owned Banks affect Credit Markets?. Rio de Janeiro, 2018. 44p. Dissertação de mestrado - Departamento de Economia, Pontifícia Universidade Católica do Rio de Janeiro.

How countercyclical macroprudential credit policies affect the loan spread? To answer this question, we propose a microeconomic model of bank competition that contemplates differences in the behavior of public and private banks and the peculiarities of the market for corporate loans vis-a-vis the market for consumer loans. We solve the model and calibrate it using parameters of the Brazilian economy, where government-owned banks not just have accounted for almost half of the outstanding loans in the credit market but also have played a strong countercyclical role in the economy. Subsequently, we use the equilibrium conditions of the model to study the effects of macroprudential credit policies on loan spreads. The results indicate that credit expansion by public banks is more effective to reduce loans interest rates during recession periods than during periods of economic expansion.

\section{Keywords}

Interest Rate Spread; Bank Competition; Public and Private Loans; 


\section{Resumo}

Capeleti, Paulo R.; Garcia, Márcio; Miessi, Fábio. Políticas Macroprudenciais em Ação: Como Bancos Públicos Afetam os Mercados de Crédito? . Rio de Janeiro, 2018. 44p. Dissertação de Mestrado - Departamento de Economia, Pontifícia Universidade Católica do Rio de Janeiro.

Como políticas macroprudenciais no mercado de crédito afetam o spread bancário? Para responder essa questão nós propomos um modelo de competição bancária que contempla diferenças de comportamento observadas entre bancos públicos e privados bem como particularidades do mercado de crédito para pessoas jurídicas vis-à-vis o mercado de crédito para pessoas físicas. Nós resolvemos o modelo e o calibramos usando parâmetros da economia Brasileira, onde os bancos públicos possuem quase metade do estoque de crédito da economia, além de terem desempenhado forte papel contracíclico no mercado de crédito nos últimos anos. Subsequentemente, nós usamos as condições de equilíbrio do modelo para estudar os efeitos de medidas macroprudenciais no mercado de crédito sobre os spreads bancários. Os resultados mostram que políticas de expansão de crédito via bancos públicos são mais eficientes em reduzir o spread quando implementadas durante períodos de recessão do que quando implementadas em períodos expansão econômica.

\section{Palavras-chave}

Spread Bancário; Competição Bancária; Crédito Público e Privado; 


\section{Table of contents}

$\begin{array}{lll}1 & \text { Introduction } & 10\end{array}$

2 Institutional Background $\quad 14$

3 The Model $\quad 19$

$\begin{array}{ll}3.1 \text { Firm } & 20 \\ 3.2 & \text { Households }\end{array}$

$\begin{array}{ll}3.2 \text { Households } & 21\end{array}$

3.3 Private Banks 23

$\begin{array}{ll}3.4 & \text { Government }\end{array}$

$\begin{array}{ll}3.5 & \text { Equilibrium } \\ \end{array}$

$4 \quad$ Calibration and Results $\quad 30$

$\begin{array}{ll}4.1 \text { Calibration } & 30\end{array}$

$\begin{array}{lll}4.2 & \text { Results } & 34\end{array}$

4.2.1 Comparative Static Exercises 34

4.2.2 Model Fit 37

$\begin{array}{lll}4.2 .3 & \text { Counterfactual Analysis } & 38\end{array}$

5 Conclusion $\quad 41$

$\begin{array}{ll}\text { Bibliography } & 43\end{array}$ 


\section{List of figures}

$\begin{array}{lll}\text { Figure 2.1 Interest Rate Spread Compared } & 14\end{array}$

$\begin{array}{lll}\text { Figure 2.2 Private and Public Credit Expansion } & 15\end{array}$

Figure 2.3 Interest Rates and One Year Interbank Rate - Annual 16

$\begin{array}{lll}\text { Figure 2.4 Banking Spread and Recovery Rates } & 18\end{array}$

$\begin{array}{lll}\text { Figure 3.1 Bank Balance Sheet } & 24\end{array}$

$\begin{array}{lll}\text { Figure 4.1 Comparative Statics Exercises } & 36\end{array}$

$\begin{array}{lll}\text { Figure 4.2 } & \text { Model Fit } & 37\end{array}$

Figure 4.3 Private Loan's Response 38

Figure 4.4 Keeping the Public Credit Policy Unchanged 39

Figure 4.5 A Sustainable Credit Expansion Policy 40 


\section{List of tables}

Table 4.1 Calibrated Parameters 


\section{Introduction}

Government owned banks have been used in many economies as a countercyclical tool during economic downturns in order to offset contractions in private loans supply and avoid extensively liquidity drops in credit markets. Nevertheless, the effect of government-owned bank's policies in credit markets is not that clear.

In contrast with the literature emerged after the 2008 Global Financial Crises (GFC) that points out the macroprudential role played by public banks in helping the market to recover from financial turmoils (see, amongst others, (8) and (3)), several works, such as (6) and (7), have advocated that government control of banks tends to be associated with distortions in the allocation of savings since bank's decisions are biased by political objectives resulting in politically connected lending problems.

As an implication, government-owned banks would not be restricted to operate countercyclical credit policies but instead they could perform non sustainable credit expansions in the economy leading to artificially lower interest rates for loans and compromising the future capacity of public banks to offset negative shocks in private credit supply during economic recessions.

To accounting for this possibility this thesis analyzes the effects of both cyclical and countercyclical public-led credit expansion on interest rates. To do that we propose a model of bank competition based on the Industrial Organization approach for banks that contemplates differences in the behavior of public and private banks and the peculiarities of the market for corporate loans vis-a-vis the market for consumer loans. We numerically solve the model and calibrate it using parameters of the Brazilian economy. Subsequently, we use the equilibrium conditions of the model to study the effects of macroprudential credit policies on loan spreads during periods of economic expansion and recession.

The Brazilian case is especially interesting because after the strong countercyclical credit policy implemented to mitigate the negative effects coming from the 2008 GFC, government-owned banks continued to expand their loans operations in a rhythm considerably faster than the private banks until at least the middle of 2015. As a matter of fact, in the second quarter of 
2012 Dilma Rousseff's administration implemented a credit policy expansion using government-owned banks to down loan spreads. In 2015 tough, those banks started to face financial fragilities to continuing with the loan expansion policy from previous years and adopted a procyclical behavior at the beginning of the recent Brazilian economic crisis. This elects Brazil as a case where government banks led credit expansion during a period without economic recessions, not being limited to perform countercyclical credit policies.

After calibrate the model, we built two counterfactual exercises based on alternative scenarios of public credit policies. In the first one, we see what would have been the loans interest rates and spreads if government-owned banks have not had presented financial fragilities to keep the track of loans expansion rates from previous years. We assume that this would lead to the maintenance of the same countercyclical policy of the period 2012-2015 to the recent economic downturn in Brazil. In the other scenario, we look at what would be the interest rates dynamics if public loans have grown in a more sustainable way between 2012 and 2014 so it did not compromise the capacity of government-owned banks to maintain positive loans expansion rates after the beginning of the economic crisis in Brazil.

Our results indicate that credit expansion by public banks would be more effective to reduce loans interest rates if it was implemented during the recession period 2015-2017 than during the period of economic expansion 20122015. Thus, there would have been a misallocation of public resources in the Rousseff's credit expansion policy per se.

In cases when the credit expansion is not financially sustainable and compromises the public banks capacity to develop countercyclical policies, it could lead to negative shocks in public credit supply just at a moment of economic downturn, when the private credit supply is also shrinking. As a result, this dynamic in public loan supply would intensify the drop in credit operations and the hike in loans spreads commonly observed in economic recessions. As we intend to show, it is what happened in the recent economic recession that took place in Brazil after the middle of 2014.

Our results show the change in credit policy in Brazil after the middle of 2015 was responsible for $26.5 \%$ of the loan interest rate hike for firms and for $33.7 \%$ of the hike for consumers. This means that even though interest rates for consumers and firms had risen due to factors not associated with the public credit policy after the first quarter of 2015 , such as the interbank rate climb and higher default risks coming from economic downturn, the adoption of a procyclical behavior in public loans supply in a moment of economic recession intensifies the hike in loans spreads . 
To build the model we use the Industrial Organization Approach for Banks. In the IO approach, the bank acts as a financial firm that intermediate the economy resources between borrowers and savers by producing deposits and loans services. We follow the baseline model of symmetric Cournot banking competition proposed by (1) and extend it to consider the distinguishing pattern of public banks behavior. We do that by considering the aggregate public loan supply as an exogenous variable in the model. The private banks, in turn, compete with each other in a Cournot style competition and solve their profit maximization problems facing the public credit supply as given.

We also use the multi-product banking firm structure presented in (4) and (5) to model the credit market separation between firms and consumers in order to consider the peculiarities of the market for corporate loans vis-a-vis the market for consumer loans ${ }^{1}$. In our model, both firms and consumers borrow from the banks. We work with the firm-households credit market separation because not just firms and households borrow for different reasons, which will probably imply distinct demand elasticities between these markets, but also because default rates for firms and households are related to different risk factors. Since the risk is one of the main components of the bank spread, it will tend to diverge between them. Besides, the credit market in Brazil is nearly shared equally between firms and households. Therefore, to understand the effects of public loans in Brazilian loan spread such extension is very helpful.

Since in our model banks chose the optimal quantity of loans in a Cournot competition framework, the interest rates are the prices that equilibrate demand and supply in the credit market. Thus, we focus our analysis in retail market not considering earmarked loans, which are credit operations with specific destinations and regulated interest rates. This is a model limitation since the dynamics of earmarked loans are likely to have impact on the path of interest rates in retail credit market.

There are a few articles discussing the effects of government-owned banks in loans market. (9) analyze the role of Brazilian government-owned banks in mitigating the effects of 2008 GFC by providing more credit to offset the decline in lending by private banks. The authors find that localities in Brazil with

\footnotetext{
${ }^{1}$ Barbosa, Rocha and Salazar investigate the competitive aspects of multi-product banking operations by proposing a model where banks offer two different financial products: Loans and other non-classical products, grouped in brokerage services, insurance and capitalization bonds. Moshe and Berg analyze the behavior of banks operating simultaneously in the retail and corporate loan segments. In our setup, tough, banks will operate simultaneously in three different markets, the credit market for firms, the credit market for households, and the bonds market, where they can buy government bonds that yield a known interest rate. We include the government's bond market in the model to account for the effect of basic interest rate rise on the bank's credit supply in Brazilian economy, since the basic rate is a good proxy for the bank's cost of fund.
} 
a high share of government banks experienced a relative increase in lending following the onset of the financial crisis compared to areas with a low share of these banks.

Regarding the literature that discusses the determinants of the loans spreads in Brazil, (11), (10) e (12) empirically identify the micro and macro variables most significantly related to banking spreads, such as the bonds interest rate, the GNP, the default rates and the bank's market power.

(4) analyze economies of scope effects on bank's market power. Using micro-data level from Financial Brazilian System, the authors find evidence that banks that produce other financial products beyond the classic ones have substantially more market power than banks that only offer classic products. (13) also investigate competition effects on credit supply and, thus, on loans spreads. The authors use the IO approach firm for banks but in a DSGE model to analyze the impact of monetary policy shocks on the loan spread in Brazil. Among the main results, they find that a increase in bank competition reduces the reaction of the interest rate spread to monetary policy shocks.

Those articles, however, by focusing in understand other channels between bank spreads and credit market features do not account for the different pattern of expansion in credit supply between public and private banks or the distinguishing aspects of firms and consumers credit market. Therefore, this paper contributes to the literature in these two dimensions.

The article is organized as follows: Section 2 discusses some key facts about Brazilian Credit Market that motivate our modeling choices; Section 3 presents the model; Section 4 shows comparative static results and counterfactual exercises followed by the Conclusion. 


\section{2}

\section{Institutional Background}

This section presents the main stylized facts about Brazilian credit market over the last years. Our goal with it is to show raw evidence that motivates our research question as well as stylized facts supporting the model that will appear next.

In 2016, despite being the ninth larger world economy, the average Brazilian spread for retail loans reached $39.65 \%$ p.y., a value much bigger than the one observed in countries facing fragile and conflict-affected situations (7.72\% p.y.) as well as least developed countries ( $8.75 \%$ p.y.). In that year, the Brazilian banking spread was the second largest in the world ${ }^{1}$.

Figure 2.1: Interest Rate Spread Compared

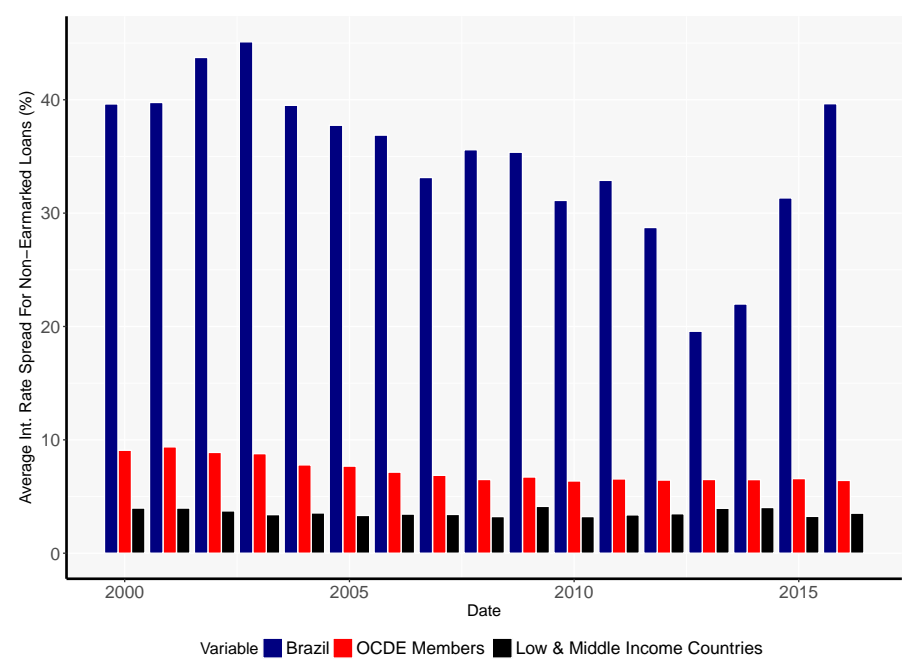

Data Source: International Monetary Fund (IMF).

In such context, the loan spread has long been an important issue in Brazil and its relevance relies not only in the high historical level of the Brazilian spread but also in its significant hike since the end of 2012, when the interest rate spread for non-earmarked loans went from $29.87 \%$ p.y. in January 2013 to 52,82\% p.y. in January 2017.

As a matter of fact, this hike could be at least partially explained by the rises of bank's cost of fund and default rates in credit operations over this

${ }^{1}$ According to World Bank Data, in a 225 countries sample, the Interest Rate Spread in Brazil is only lower than the one in Madagascar. 
period, specially after the middle of 2014 when the recent economic downturn in Brazilian economy begins. Furthermore, we intend to show some evidence that the macroprudential credit policy extensively implemented in Brazilian economy was also key variable to understand the rise in retail credit market spread after 2014.

On August 2012, after the Central Bank brought the benchmark overnight Selic interest rate to $7.5 \%$, a full $5 \%$ drop from a year earlier, Dilma Rousseff's administration turned its focus to down bank spreads. For that, the government used public banks, the Banco do Brasil e the Caixa Econômica Federal, to reduce the spread of their main credit lines. As a result, this policy increased the market share of public banks to almost $50 \%$ of the total assets in credit market in February 2013.

In the middle of 2014, however, public banks started to face financial fragilities to continue with the credit expansion policy from previous years. As consequence, the expansion pattern of public loans was replaced by a policy of contraction in public loan supply just in a period of economic recession. Thus, in the recent Brazilian economic crisis, the government-owned banks were no longer able to offset a fall in credit supply from private banks as before. In 2016, public loans also became to shrink the credit supply together with the private banks, intensifying the reduction in total credit supply and, hence, the rise in interest rates for credit operations.

The data in Figure 2.2 shows that in September 2009, when outstanding private loans stagnated growing only $0,8 \%$ in relation to September 2008, public outstanding loans grew up 31,4\%. However, the macroprudential intervention in credit market have not stopped after the main effects of 2008 crises passed way and public loans continued to expand in Brazilian economy showing annual expansion rates above $10 \%$.

Figure 2.2: Private and Public Credit Expansion

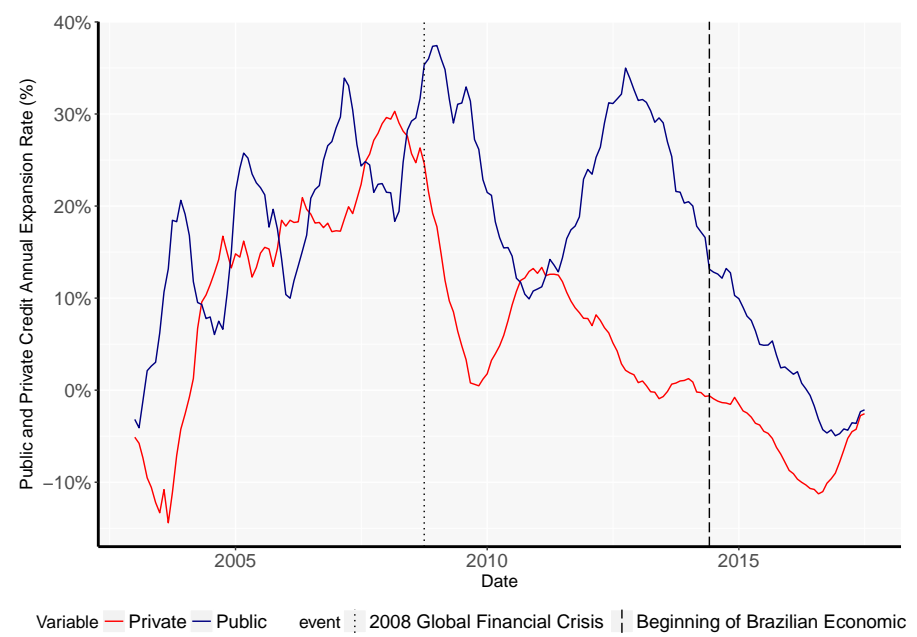


Therefore, government-owned banks were not restricted to operate countercyclical credit policies during the period of 2012-2015 in Brazil. Instead, they perform a strong credit expansion policy in the economy which could lead to artificially lower interest rates for loans.

Another stylized fact about Brazilian Credit Market that was influent to our modeling proposition also comes from the supply side of the loans market. In January 2016, five banks whose $82.8 \%$ of outstanding loans in Brazil. ${ }^{2}$ To capture this high level of concentration, we adopt an oligopolistic structure to model competition in banking credit market. Like (1), banks will play a symmetric Cournot game choosing the optimal quantity of loan supplied to the borrowers. Ceteris paribus, the model predicts that the more concentrated the market, higher is the interest rate charged by the banks in credit operations.

Another stylized fact is that the one-year interbank market rate, which is taken as a conventional proxy of banking cost of funding, increased from $7.2 \%$ p.y. in January 2012 to $15.3 \%$ p.y. in January 2016. Although the cost of funding does not configure a spread component, its rise does not imply a rise in the same proportion in loans interest rate. As pointed out by the literature, like in (1) and (13), as the intensity of competition in banking market increases, the loan interest rate becomes less sensitive to changes in the cost of funding.

The IO approach for banking competition captures the stylized fact that the basic interest rate emerges as an opportunity cost faced by banks in credit operations since they are able to use funds to grant loans or buy government bonds. Therefore, a rise in bonds interest rate will lead to a fall in loan supply, raising the interest rate on credit operations. Nevertheless, Figure 2.3 show that this effect seems to be different between firms and consumers credit market.

Figure 2.3: Interest Rates and One Year Interbank Rate - Annual
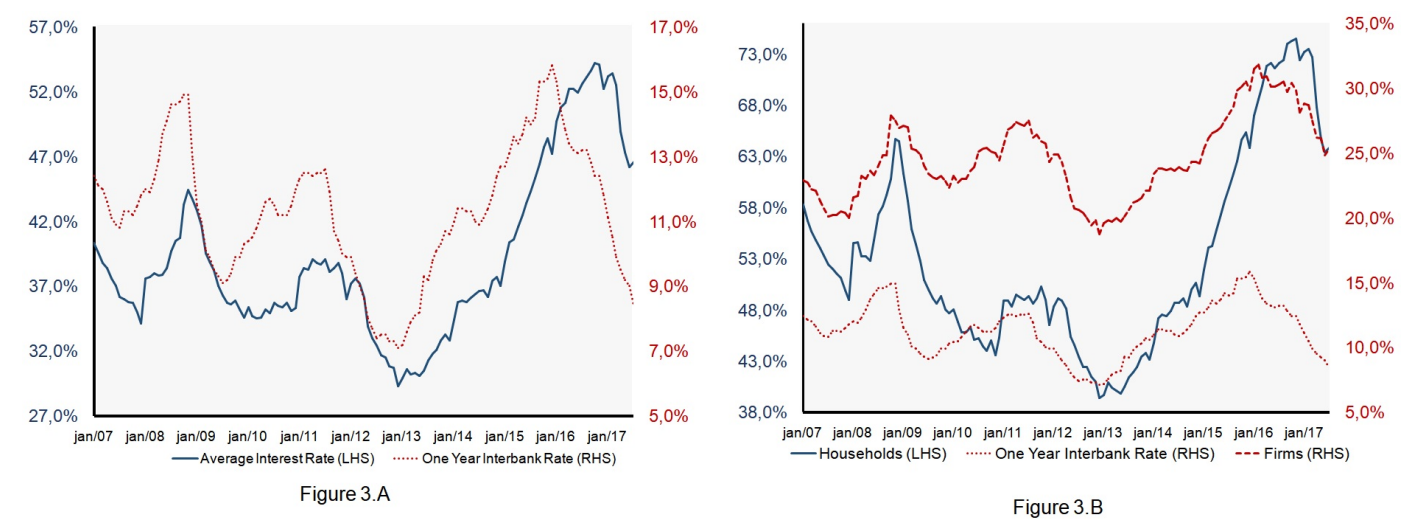

The figure shows the one-year interbank market rate (on the right-hand ${ }^{2}$ Source: Time Series Management System of Brazilian's Central Bank. 
side) and the interest rate for retail loans. As expected by the theory, rises in banking cost of funding keeps up with higher interest rates for loans. Nevertheless, when we decompose the non-earmarked interest rate between firms and consumers, as shown in Figure 2.3.B, we see that the interest rate for loans has distinguishing patterns between those markets.

According to the data, variations in the cost of funding are associated with stronger movements in consumers interest rate than in the firm's one. In fact, given the rise in the cost of funding between January 2013 and January 2017, while the nominal interest rate for firms rose $47.1 \%$ over the period, the interest rate grew $84.3 \%$ in consumers market. Another important feature is that the interest rate for consumers is considerably higher than the one charged for firms. There are several reasons that can explain these differences between those credit markets. One of them is that consumer's default rates are historically higher than the firm's one, what leads to a higher spread in consumers market through the risk channel. Another reason is that firms have access to more options of funding than consumers, who are more dependent on retail banks to access credit services.

As a result, banks would have higher market power in consumers credit market when compared to firms credit market. Indeed, (14) ${ }^{3}$ estimate credit demand elasticities in Brazilian economy and found that consumer credit demand is quite inelastic while firm credit demand is elastic. We use the authors estimations of loan demand elasticities to calibrate demand parameters in the model.

Finally, Figure 2.4 shows the last stylized fact about the Brazilian economy considered in our model. The figure shows the correlation between the spread for retail loans and the average recovery rate in a sample of 113 countries in 2016. Note that as the recovery rate is the fraction of the initial loan that a bank can recover in case of a borrower default, it is a measure of law enforcement and property rights in the economy.

The data shows a negative correlation between the recovery rate and the banking spread, what is likely to be expected since a lower recovery rate would imply a higher risk in credit operations, rising loans interest rate. Following this line, this can be an important feature to understand the huge Brazilian spread, since Brazil has one of the most lower recovery rates in the sample. As a matter of fact, for each dollar lent by Brazilian banks, they just expected to recover 0.158 cents in case of default. However, Brazilian is an outlier in

${ }^{3}$ Based on the heteroskedasticity approach method proposed by (15), the authors use daily frequency credit data from $\mathrm{BCB}$ to estimate the interest-rate elasticity of firms and consumers credit demand. 
Figure 2.4: Banking Spread and Recovery Rates

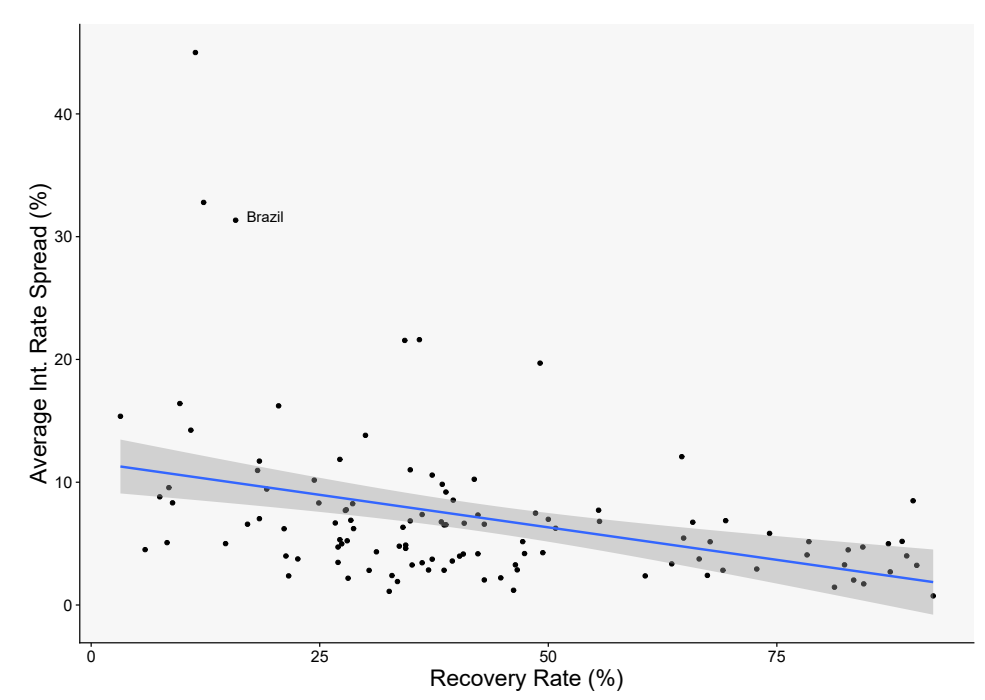

Note: The data was collected from the World Bank Report. The line is the fitted linear regression.

the sample since the $32.4 \%$ p.y. Brazilian spread is much higher than the average of $12.3 \%$ p.y. observed in countries with similar recovery rates. This suggests that, although the law enforcement is a relevant issue, there are other important factors leading to the overhead Brazilian spreads besides the risk associated with weak enforcement in credit operations.

In our model, when a bank lends to a borrower, whether he is a firm or a consumer, he can recover a fraction of the initial loan in case of default. This fraction is calibrated to reflect the data showed above.

We use these stylized facts about Brazilian credit market to support the model that will appear next. The main fact, however, relies on the significant participation of government-owned banks in credit markets and the fact that they have performed a strong policy of credit expansion in a procyclical way, i.e., they considerably increase credit operations when the economy was expanding. However, after the beginning of the recession period in 2014, the public banks started to shirk their new loans transactions once they were no longer able to continue with their previous credit police. This dynamic could intensify the drop in credit operations and the hike in loans spreads commonly observed in economic recessions, and this is exactly what we are going to check in the result's section after we show the model. 


\section{3}

\section{The Model}

The economy is represented by a two-period model composed of four types of agents, namely: households, firms, banks, and the government. There is a continuum of households indexed in the unit interval which is divided into $\lambda$ impatient and $1-\lambda$ patient households, $\lambda \in(0,1)$. There is a representative firm who produces a final consumption good demanding labor from households and working capital directly from the banks, which are divided into public and private ones. Private banks form a set of $I$ identical banks that intermediate among the savers, the borrowers and the firms. The banks also have access to a treasury bond market. Public banks, on the other hand, are represented by one government-owned bank which has an exogenous credit supply. The government, through the representative public bank, closes the model operating a credit policy that is financed not just by bonds emissions to the banking system but also by a lump-sum tax charged from the households.

In the first period, agents make their decisions under uncertainty about the future state of the economy, which will only be known in the second period. This uncertainty comes from a productivity shock represented by a random variable $z$, whose distribution $f(z)$ is known for all the agents in the economy. ${ }^{1}$ Thus, both firms and households demand loans in the first period based on their expectations about future incomes. The loan repayment by them will depend, however, on the realization of $z$. In a sufficiently bad state of the economy in the second period, i.e., if $z$ is very low, they both can default the banks.

While the firm does not pay the banks when her revenue is not enough to cover the loan plus interests, the default risk in consumers credit market comes from the possibility of a worker be fired by the firm in the second period. To generate this possibility in the model, we assume that the firm has to train the labor force in order to employ it in production in the second period. Thus, in period two the firm will have at its disposal for production the working capital that it takes from the banks as well as an amount of trained workforce. The difference between those two production inputs though is that while the cost

\footnotetext{
${ }^{1}$ In order to ensure only positive values for $z$, we assume that $f(z)$ is a lognormal distribution with mean $\mu$ and standard deviation $\sigma, f(z) \sim \operatorname{lognormal}(\mu, \sigma)$.
} 
of capital is given in the second period, the labor cost is not. The firm has a possibility to not use some trained workers in production if the productivity shock is low since she will not have to pay the salary of equilibrium $w$ to workers not used in production, just the cost of training, which we denoted by $s$. We define the ratio between the labor not used in production $N_{d}$ and the labor previously hired by the firm to the training $N$ as our economy unemployment rate $u$.

\section{1}

\section{Firm}

The production function $Y=F(K, N)$ is assumed to be neoclassical, i.e., for positive input values, the technology is increasing and concave with respect to each production factor. We assume the firm has access to a decreasing return to scale technology ${ }^{2}$ which is represented by a Cobb-Douglas functional form. The firm's profit maximization problem in first and second period is described as follows:

Firm's Problem t=1

$$
\operatorname{Max}_{N, K} E_{0}\left\{\pi(z \mid N, K)=z N_{p}^{\alpha} K^{\psi}-(w+s) N_{p}-s\left(N-N_{p}\right)-\left(1+r_{f}\right) K\right\}
$$

Firm's Problem t=2

$$
\begin{gathered}
\operatorname{Max}_{N_{p}, N_{d}} z N_{p}^{\alpha} \bar{K}^{\psi}-(w+s) N_{p}-s N_{d}-\left(1+r_{f}\right) \bar{K} \\
\text { st } N_{p}+N_{d} \leq \bar{N}
\end{gathered}
$$

Where $r_{f}$ is the net interest rate charged by the banks to lend working capital $K$ to the firm and $w$ is the salary paid per hour worked. The firm solves her problem by backward induction choosing first the optimal amount of labor used in production $N_{p}$ as well as the labor not used in production $N_{d}$ for each realization of $z$. The solution for $N_{p}$ is given by

$$
N_{p}^{*}=\min \left\{\left(\frac{\alpha z \bar{K}^{\psi}}{w}\right)^{\frac{1}{1-\alpha}}, \bar{N}\right\}
$$

Or putting it in another way

$$
N_{p}^{*}=\left\{\begin{array}{cl}
\left(\frac{\alpha z \bar{K}^{\psi}}{w}\right)^{\frac{1}{1-\alpha}}, & \text { if }\left(\frac{\alpha z \bar{K}^{\psi}}{w}\right)^{\frac{1}{1-\alpha}}>\bar{N} \\
\bar{N}, & \text { if }\left(\frac{\alpha z \bar{K}^{\psi}}{w}\right)^{\frac{1}{1-\alpha}} \leq \bar{N}
\end{array}\right.
$$

What sets a threshold $\Gamma_{n}$ for productivity shock distribution which determines

${ }^{2}$ This condition ensures a real and limited solution to firm's problem. 
the set of $z$ realizations where the firm operates under the labor constraint given by

$$
\Gamma_{n}=\frac{w \bar{N}^{1-\alpha}}{\alpha \bar{K}^{\psi}}
$$

Plugging second period solutions in period one problem, the firm solves following problem

$$
\begin{gathered}
\operatorname{Max}_{N, K}=E\left[\pi(z) \mid z \leq \Gamma_{n}\right] p\left(z \leq \Gamma_{n}\right)+E\left[\pi(z) \mid z>\Gamma_{n}\right] p\left(z>\Gamma_{n}\right) \\
\equiv \\
\operatorname{Max}_{N, K}=\int_{0}^{\Gamma_{n}}\left\{z\left(\frac{\alpha z K^{\psi}}{w}\right)^{\frac{\alpha}{1-\alpha}} K^{\psi}-w\left(\frac{\alpha z K^{\psi}}{w}\right)^{\frac{1}{1-\alpha}}-s N-\left(1+r_{f}\right) K\right\} f(z) d z \\
+\int_{\Gamma_{n}}^{+\infty}\left\{N^{\alpha} K^{\psi}-w N-\left(1+r_{f}\right) K\right\} f(z) d z
\end{gathered}
$$

Finally, we solve the system of equations formed by the first order conditions in relation to capital and labor of problem (3-2) in order to get the optimal solutions $N^{*}$ and $K^{*}$, which are the demand for labor and for working capital in our economy.

\section{2}

\section{Households}

From the households side we assume that consumers maximize their expected utility function by solving a two-period consumption-saving problem under uncertainty. Consumers are from two types, impatient (borrowers), with intertemporal discount rate $\beta_{b}$ and patient (savers), who have intertemporal discount rate $\beta_{s}$, such that $\beta_{s}>\beta_{b}$. We assume they are indexed in the unit interval which is divided into $\lambda$ impatient and $1-\lambda$ patient households, $\lambda \in(0,1)$.

For simplicity, we assume that impatient households are the workers in our economy, who only receive income from labor. Thus, the income uncertainty for them comes only from the firm's probability to not pay salaries. On the other hand, patient households own the firm and the banks receiving income from firm's and bank's profits and also from deposits yields. Besides, we assume that saver's income from the second-period is lump sum taxed ${ }^{3}$. The saver's problem is given by

${ }^{3}$ As we are going to show in bank's section, the optimal quantities of loans supplied by the banks as well as the interest rates for firms and consumers will not depend on deposit market. 


\section{Saver's Problem:}

$$
\max \log \left(c_{1}^{s}(i)\right)+\beta_{s} E_{0}\left\{\log \left(c_{2}^{s}(i)\right)\right\}
$$

st.

$$
\begin{gathered}
c_{1}^{s}(i)+d(i)=\bar{w}_{1}^{s}(i) \\
c_{2}^{s}(i)=\left(1+r^{d}\right) d(i)+y(i)+t(i)
\end{gathered}
$$

The household utility function is assumed to take a logarithmic form. The budget constraint in first-period consists of an initial endowment that can be allocated between present consumption $c_{1}^{s}(i)$ or be saved through deposits $d(i)$. In the second period, savers receive the deposits plus its interest rate $\left(1+r^{d}\right) d(i)$ as well as the profits from the banks and the firm $y(i)$ net from the lump sum tax $t(i)$. The first order condition in relation to $d(i)$ defines the deposit supply for the banks

$$
\frac{1}{\beta_{s}\left(1+r^{d}\right)}=E_{0}\left\{\frac{\bar{w}_{1}^{s}(i)-d(i)}{\left(1+r^{d}\right) d(i)+y(i)+t(i)}\right\}
$$

Note that in our model the saver's uncertainty is related not just to the deposits return - since banks could also default the savers - but also to the profits and the lump sum taxes, which will both depend on the productivity shock. The firm's profit is directly affected by it. The lump sum tax will depend on the public bank profit, which depends, in turn, on the $z$ realizations ${ }^{4}$.

Regarding to the impatient household (borrower) problem, it is described below.

\section{Borrower's Problem:}

$$
\max \log c_{1}^{b}(i)+\beta_{b} E_{0}\left\{\log \left(c_{2}^{b}(i)\right)+\varepsilon \log (T-n(i))\right\}
$$

st.

$$
\begin{gathered}
c_{1}^{b}(i)=\bar{w}_{1}^{b}(i)+l(i) \\
c_{2}^{b}(i)+\left(1+r^{c}\right) l(i)=w n(i)
\end{gathered}
$$

The borrower maximizes an intertemporal utility function that depends on consumption over the two periods $c_{1}^{b}(i)$ and $c_{2}^{b}(i)$ and leisure in period two, which can be expressed in terms of the total endowment of time $T$ - which

${ }^{4}$ The dependency between tax and the productivity shock is shown in the government section. 
we normalize to 1 - minus the hours of labor supplied to the firm $n(i)$. The borrower's income in the first period consists of an initial wealth $\bar{w}_{1}^{b}(i)$ and an amount of credit demanded by him from the banks $l(i)$. When he receives a full salary from the firm, he pays the loan plus its interests $\left(1+r^{c}\right) l(i)$ at a $r^{c}$ net interest rate and consumes $c_{2}^{b}(i)$ using his income from labor $w n(i)$. Note that if a borrower is not paid in period-two he automatically default to the banks because the salary is his only income in period-two.

The first order conditions of borrower's problem are

FOC $L_{c}$

$$
\frac{1}{\beta_{b}\left(1+r^{c}\right)}=E_{0}\left\{\frac{\bar{w}_{1}(i)^{b}+l(i)}{w n^{b}(i)-\left(1+r^{c}\right) l(i)}\right\}
$$

FOC $N$

$$
\frac{w}{\varepsilon}=E_{0}\left\{\frac{w n(i)-\left(1+r^{c}\right) l(i),}{1-n(i)}\right\}
$$

The solution of equations (3-4) and (3-5) will lead to the labor supply $n\left(w ; r^{c}\right)$ and the households demand for loans $l\left(r^{c} ; w\right)$. As in the firm's case, equations (3-4) and (3-5) also demand a numerical solution.

\section{3}

\section{Private Banks}

Private banks intermediate the economy resources between savers, from one side, and firms and borrowers, on the other. They are financed through deposits by the savers $(D)$ and allocate them in three different markets: the credit market for firms $\left(L_{f}\right)$, the credit market for households $\left(L_{c}\right)$ and the bonds market $(B)$. We denote the fraction of reserve requirements stipulated by the Central Bank by $\rho$. Thus, the total resources available to the bank to be applied in credit and bond's market is $(1-\rho) D$. Figure 3.1 illustrates the bank's balance sheet. 
Figure 3.1: Bank Balance Sheet

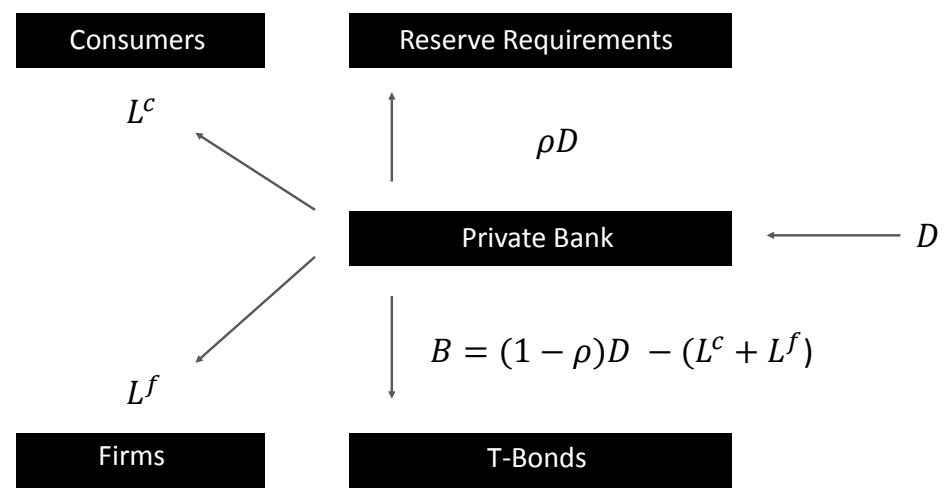

In the IO approach banks are taken as firms that produce deposits and loan services. To do that, each bank has a technology given by a cost function $C\left(L_{i}^{f}, L_{i}^{c}, D_{i}\right)$ which depends on the credit volume supplied to firms $L_{i}^{f}$ and households $L_{i}^{h}$ and the amount of deposits managed by the bank $D_{i}$. Following (16) and (13), we assume constant returns to scale as well as additive separability in the banks cost function. These assumptions imply that

$$
\frac{\partial C}{\partial L_{i}}=\gamma_{L} \quad \frac{\partial C}{\partial D_{i}}=\gamma_{D} \quad \frac{\partial^{2} C}{\partial L_{i} \partial D_{i}}=0
$$

Where $\gamma_{L}$ and $\gamma_{D}$ are the marginal costs of loans and deposits operations. For simplicity, we assume that the marginal cost is the same to firms and consumers loans. With the separability assumption, the decision problem faced by the bank in credit markets is separable from the deposit market. So, the optimal loan interest rate will not depend on features of the deposit market, and vice versa. ${ }^{5}$

In its profit maximization problem, the bank allocates his portfolio according to the expected return in each market, which will depend on the default probabilities of firms and households. The bank problem can be described as

$$
\begin{array}{r}
\operatorname{Max} \pi\left(L_{i}^{f}, L_{i}^{h}, B_{i}, D_{i}\right)=E\left[r^{f}\left(L^{f}\right) L_{i}^{f}\right]+E\left[r^{c}\left(L^{c}\right) L_{i}^{c}\right]+\left(1+r_{b}\right) B_{i} \\
-\left(1+r_{d}\right) D_{i}-C\left(L_{i}^{f}, L_{i}^{c}, D_{i}\right)
\end{array}
$$

subject to its balance sheet equilibrium

$$
L_{i}^{f}+L_{i}^{c}+B_{i}=D_{i}(1-\rho)
$$

${ }^{5}$ Since we are interested in as specific channel, which are the competitions effects between public and privet banks on the interest rate spread, this assumption simplifies the analyses and does not harm the thesis conclusions. 
$B_{i}$ denotes the bonds bought by the bank $i$ that yield a known net interest rate $r_{b}$ and $D_{i}$ is the amount of deposits remunerated by the bank at $r_{d}$ net interest rate. $E\left[r^{f}\left(L^{f}\right) L_{i}^{f}\right]$ and $E\left[r^{c}\left(L^{c}\right) L_{i}^{c}\right]$ are the expected return in firms and households credit market, respectively. $r^{f}\left(L^{f}\right)$ and $r^{c}\left(L^{c}\right)$ are the inverse demand functions faced by the bank in each market. Since the banks play a Cournot competition game, $r^{f}\left(L^{f}\right)$ and $r^{c}\left(L^{c}\right)$ are functions of all the other bank's credit supply, including the exogenous aggregated public loan supply $L_{G}$.

$$
r^{j}\left(L^{j}\right)=r^{j}\left(\sum_{i=1}^{I} L_{i}^{j}+L_{G}^{j}\right), j=f, c .
$$

As private banks face a downward sloped demand curve in both markets, a higher quantity of loans provided by public banks, ceteris paribus, drops the loan interest rate in equilibrium.

Given the demand functions, we can characterize the expected returns on credit operations in each market. As mentioned before, the default probability in firm's market comes from the probability of the firm's profit $p\left(\pi_{f}(z)<0\right)$ become less than zero while the default probability in households market comes from the probability there are associated with the chance of a worker who borrows from the bank do not be used in production by the firm in period two, this is, being fired.

The bank expected return in firms credit market is given by ${ }^{6}$

$$
E\left[r^{f}\left(L^{f}\right) L_{i}^{f}\right]=\int_{\sigma_{f}}^{+\infty}\left[1+r^{f}\left(L^{f}\right)\right] L_{i}^{f} f(z) d z+\delta \int_{0}^{\sigma_{f}} r(z) L_{i}^{f} f(z) d z
$$

Where $\sigma_{f}=\sigma_{f}\left(K, N ; w, r^{f}, s\right)$ is the threshold value that defines the realization of $\mathrm{z}$ where the firm has profit lower than zero and stops to fully pay the bank to give him a partial default. In other words, $\sigma_{f}$ is defined as the value of $z$ that equals the firm's profit to zero. When it happens, although the firm has not enough revenue to pay all the loan she took, she still has a return $r(z)$ that can be appropriated by the bank. The capacity of appropriation of firm's result by the bank in case of default is related to a enforcement parameter $\delta$, $\delta \in[0,1]$. A higher law enforcement in the economy drops the bank losses in case of default, which will lead to a higher credit supply by the banks. The firm's return when she incurs in partial default is given by

$$
r(z)=\frac{z N^{\alpha} K^{\psi}-(w+s) N_{p}-s N_{d}}{K} \quad \text { when } \pi(z)<0
$$

${ }^{6}$ In order to simplify the exposition, we show the algebraic derivation of expected returns in the Appendix. 
The return $r(z)$ is defined by the ration between the revenue liquid from labor costs in period-two and the loan borrowed by the firm in order to finance her working capital in period 1 . On the other side, when the firm does not default the bank it receives the gross equilibrium interest rate $1+r_{f}\left(L^{f}\right)$ multiplied by the quantity of loan it lent to the firm $L_{i}^{f}$.

On the other hand, the expected return in consumers credit market is given by

$$
E\left[r^{c}\left(L^{c}\right) L_{i}^{c}\right]=\int_{\Gamma_{n}}^{+\infty}\left[1+r^{c}\left(L^{c}\right)\right] L_{i}^{c} f(z) d z+\delta \int_{0}^{\Gamma_{n}} \frac{N_{p}(z)}{N}\left[1+r^{c}\left(L^{c}\right)\right] L_{i}^{c} f(z) d z
$$

Where $\Gamma_{n}=\Gamma_{n}(N, K ; w)$ is the threshold that comes from the inequality (3-1) in firm's problem. When $z$ assumes a value that the firm does not dismiss any worker, i.e. $z>\Gamma_{n}$, we have $N_{p}(z) / N=1$ and all borrowers pay the bank. Since only the borrowers who are not fired by the firm do not default the banks, when $0<z<\Gamma_{n}$ the bank only receives the loan repayment plus its interest from the mass of borrowers who receives salary, which we denote by $N_{p}(z)$. Thus, when the $z$ realization is such that a positive mass of borrowers do not pay the bank it only receives $\left[1+r^{c}\left(L^{c}\right)\right] L_{i}^{c}$ from the mass of borrowers used in production. Since all borrowers are equal they work the same numbers of hours to the firm and the mass of borrowers who repay the loans can be given by $N_{p}(z) / N$. What a bank can recover in this situation will also depend, as in firm's credit market, of the enforcement parameter $\delta$.

Finally, since the deposits market does not affect the credit market equilibrium we assume perfect competition in this market to simplify analytical derivations.

The first order conditions with respect to $L_{i}^{f}, L_{i}^{c}$ and $D_{i}$ defines the optimal amount of loans supplied by the bank in firm's and household's credit market as well as the optimal amount of deposits. Defining the unemployment rate as $u(z)=\frac{N-N_{p}(z)}{N}$, the first order conditions are given by

FOC $L_{i}^{f}$

$$
\left[1+r^{f}\left(L^{f}\right)+r^{f^{\prime}}\left(L^{f}\right) L_{i}^{f}\right] P(\pi(z)>0)+\delta E[r(z) \mid \pi(z) \leq 0]-\left(1+r_{b}+\gamma_{L}\right)=0
$$

FOC $L_{i}^{h}$

$$
\left[1+r^{c}\left(L^{c}\right)+r^{c \prime}\left(L^{c}\right) L_{i}^{c}\right]\left\{1-E\left[u(z) \mid z<\Gamma_{n}\right]\right\} \delta-\left(1+r_{b}+\gamma_{L}\right)=0
$$

FOC $D_{i}$

$$
\left(1+r_{b}\right)(1-\rho)-\left(1+r_{d}\right)-\gamma_{D}=0
$$


While equations (3-9) and (3-10) define the optimal loans amount in credit markets, equation (3-11) defines the equilibrium between the bonds and deposits market. In the model, the bond's interest rate, which is the bank's opportunity cost to grant loans for firms and households, depend on the reserve requirements and the deposit's interest rate through the following equilibrium relation

$$
1+r_{b}=\frac{1+r_{d}+\gamma_{D}}{1-\rho}
$$

Thus, a higher reserve requirement will lead to a smaller loans supply by increasing the bank's opportunity cost to provide loans. Since we use the bond's interest rate as exogenous variable in the model, we are already capturing reserve requirements effects on credit supply through the equilibrium relation give by the equation (3-12).

Finally, we describe the role played by the government in the model.

\section{4}

\section{Government}

The government closes the model satisfying its budget constraint. In the first period, he plays a credit policy lending credit to firms $L_{G}^{f}$ and households $L_{G}^{c}$. This policy, which is exogenously given in the model, is financed through bonds emissions to the financial system. The government credit policy in $t=0$ is such that

$$
L_{G}^{f}+L_{G}^{c}=B
$$

In the second period the banks pay for the bond's interests, which is given by an exogenous rate $r^{b}$. Plus the revenue obtained in bond's market, the government also receive the profits of public banks and the lump sum taxes in second period, when its budget constraint is

$$
\left(1+r^{b}\right) B=L_{G}^{h}\left(1+r^{h}\right)(1-u(z))+\left.L_{G}^{f}\left(1+r^{f}\right)\right|_{\pi(z)>0}+\left.L_{G}^{f} \frac{R(z)}{L^{f}}\right|_{\pi(z)<0}+T
$$

Replacing (13) in 14), we have a single government budget constraint 
that determines lump sum taxes and is given by

$$
\begin{gathered}
T(z)=L_{G}^{h}\left[\left(1+r^{b}\right)-\left(1+r^{h}\right)(1-u(z))\right] \\
+L_{G}^{f}\left[\left(1+r^{b}\right)-\left.\left(1+r^{f}\right)\right|_{\pi(z)>0}-\left.\frac{R(z)}{L^{f}}\right|_{\pi(z)<0}\right]
\end{gathered}
$$

Therefore, lump sum taxes will also depend on the $z$ realizations. In this model, although the countercyclical policy leads to a lower interest rate for firms and households in equilibrium, it has the cost to increases the taxes on patient households, what is partial offset in the well-fare gain from a lower interest rate spread.

\section{5}

\section{Equilibrium}

Our model is evaluated at a symmetric Cournot equilibrium in credit market. The optimal solutions coming from bank's, firm's and household's problem and the market clearing conditions define our equilibrium, which we described bellow.

The Equilibrium Definition : Given a public credit policy $\left\{L_{G}^{f}, L_{G}^{h}, B\right\}$, a basic interest rate $r_{b}$ and a productivity shock distribution $f(z)$, the equilibrium is a sequence of prices $\left\{w, r_{c}, r_{f}\right\}$ and a set allocations set $\left\{C_{t}^{i}, N^{s}, D^{i}, N^{d}, K, L^{f}, L^{h}, T\right\}_{t=0,1}^{i=b, s}$ such that

I) The firm solves its intertemporal problem (1) under $N_{p}+N_{d} \leq N$.

II) The borrowers and the savers solve their problems (2) and (3) under their budget constraints.

III) The private banks solve their profit maximization problems (3-6), leading to an Unique ${ }^{7}$ Nash Equilibrium in Banking Sector.

IV) All Markets Clear ${ }^{8}$ :

$$
\begin{gathered}
\sum_{i=1}^{I} L_{f i}^{s}+L_{f G}^{s}=K^{d} \quad\left(\text { Firm's }^{\prime} \text { Credit Market }\right) \\
\sum_{i=1}^{I} L_{c i}^{s}+L_{c G}^{s}=L_{c}^{d}=\int_{0}^{\lambda} l^{d}(i) d i \quad(\text { Household's Credit Market }) \\
B=(1-\rho) \int_{0}^{1-\lambda} d^{s}(i) d i-\sum_{i=1}^{I} L_{i}^{f}-\sum_{i=1}^{I} L_{i}^{f} \quad(\text { Bond's Market })
\end{gathered}
$$

${ }^{7}$ Since all the banks are symmetric and face well behaved downward sloped demand curves for loans in both firms and consumers market, the Nash equilibrium is unique.[see (17)]

${ }^{8}$ We index the demanded quantities by the letter $d$ and supplied quantities by the letter $s$. 


$$
\begin{gathered}
\sum_{i=1}^{I} D_{i}=\int_{0}^{1-\lambda} d^{s}(i) d i \text { (Deposit's Market) } \\
N^{d}=N^{s}=\int_{0}^{\lambda} n^{s}(i) d i \quad(\text { Labor Market })
\end{gathered}
$$




\section{4}

\section{Calibration and Results}

\section{1}

\section{Calibration}

For the calibration of the parameters, we adopt the following strategy:

1. We use parameters estimated for the Brazilian economy in (13) and for U.S. economy when estimations for the Brazil were not available.

2. The parameters that build the demand for loans from firms and consumers were calibrated in order to replicate the demand elasticities for loans in Brazil estimated by (14).

3. The parameters of the financial system were calibrated based on the average found in the data of Brazilian economy in 2010, which is our starting year when performing counterfactual analysis.

4. The other parameters were calibrated so as to ensure consistency with the data for the main economic relations in equilibrium.

In order to preserve a reasonable time duration for the agent's planning horizon in our two-period setup as well as use sufficiently data observations to ensure a robust analysis, we consider that each period has a duration of a quarter.

Regarding the parameters of the logarithmic utility function, we set $\varepsilon=1.4317$, this value was estimated by GMM in (13) for Brazilian economy and is consistent with the calibrations of our other parameters and the model outputs. The impatient intertemporal discount rate $\beta_{b}$ was set at 0.9153 , a similar value estimated by Alencar and Nakane of 0.9140 . Both $\beta_{b}$ and the borrower's initial endowments $W_{0}^{b}$, which we set to 0.121 , were chosen to reproduce an inelastic demand function for loans from the households as well as to ensure consistency between the data and the model outputs. Since the parameters from patient households have no practical consequences for the qualitative conclusions of the model economy we consider them as arbitrary normalizations.

The parameters $\alpha$ and $\psi$ from the Cobb-Douglas production function 
were set in order to reproduce two features of Brazilian data. The first one is the high elasticity of credit demand by the firms, which was estimated by (14) to be between -1.8 and -2 , from those we take the average -1.9 . The second one is the average share of labor and capital observed in National Accounts. To satisfy both conditions we set $\alpha=0.428$ and $\beta=0.285$. The cost of training $s$, in turn, was calibrated to 0.3105 in order to get consistent values for the expected unemployment rate in our economy.

There are no available estimations for operational costs associated with the loan and deposit activities for Brazilian banks. We then use the estimates reported by (16) for the U.S. economy. The value estimated by the authors are $0.11875 \%$ for the marginal cost of deposits $\eta_{D}$ and $0.5625 \%$ for the marginal cost of loans. We consider that the loans have the same marginal cost whether they are made for the firms or consumers. The reserve requirements ratio on deposits was set at $\rho=0.45$, which is close to the average values observed in Brazil.

Based on Central Banking data from December 2001, (13) set in 40 the number of private banks in their model. To work just with banks that have their main activities in the retail credit market, as our model requires, the authors select the banks who have more than 10 branch networks among a set of 160 banks operating in retail markets, since retail banks usually have large branch networks.

To deal with banks who have less than 10 branches, we use the data of financial conglomerates from Balancetes e Balanços Patrimoniais available in $\mathrm{BCB}$ website. In the data, there were 66 financial conglomerates operating in retail credit market in January 2010 in Brazil. However, since just 5 of them accounted for $81.43 \%$ of the total outstanding loans (including two governmentowned banks Banco do Brasil and Caixa Econômica Federal), we understand that the market share should also be considered to calibrate the number of banks to replicate the high level of bank concentration. Since we have to adapt theses number to our model of symmetric banks, we then set the number of private banks to 16 . With such calibration we consider the stylized facts from the data and preserve the consistent economic relations in equilibrium.

The institutional parameters of enforcement $\delta$ was set in 0.158 to match the value of the recovery rate in Brazilian economy calculated by the Word Bank in 2016.

Finally, we calibrate the average and standard deviation parameters of the productivity shock distributive function in order to match the bank's expected fraction of defaults with observed default rates in firms and consumers credit market in Brazilian economy between 2010 and 2017. Thereby, we 
capture the risk dynamics in the economy through the productivity shock distribution in each period. Table 4.1 resumes the model parameters values.

Table 4.1: Calibrated Parameters

\begin{tabular}{clc}
\hline Parameters & Description & Values \\
\hline$\beta_{P}$ & Patient Households & 0.9890 \\
$\beta_{I}$ & Impatient Households & 0.9153 \\
$\varepsilon$ & Labor parameter Log Utility Function & 1.4317 \\
$\alpha$ & Labor Share Cobb-Douglas Production Function & 0.4286 \\
$\psi$ & Working Capital Share Cobb-Douglas Production Function & 0.2857 \\
$s$ & Labor Cost of training & 0.3105 \\
$I$ & Number of Private Banks & 16 \\
$\lambda$ & Fraction of impatient households & 0.212 \\
$\gamma_{L}$ & Cost per Unit Value Loans & $0.5625 \%$ \\
$\gamma_{D}$ & Cost per Unit Value Deposits & $0.11875 \%$ \\
$\delta$ & Recovery Rate & 0.1580 \\
$\rho$ & Reserve Requirements Ratio on Deposits & 0.45 \\
$W_{0}^{b}$ & Borrower's Endowment & 0.2501 \\
$W_{0}^{s}$ & Saver's Endowment & 0.8243
\end{tabular}

We also use 3 macroeconomic variables of the Brazilian economy that are exogenously given in the model. The new transactions of public loans to firms and consumers and the one year interbank market rate.

As in our model banks optimally choose how much to lend for firms and consumers in each period, this amount of credit corresponds to a new transaction of loans in the economy. However, we did not have access to new transactions of loans in Brazil, since there is no open data source for new loans categorized between public and private banks. To recover new loans transactions of public loans we did a reverse engineering procedure by getting new transactions from outstanding loans, which are openly available in the Balancetes e Balanços Patrimoniais database stored in BCB website ${ }^{1}$. This database has the balance sheet of all Brazilian financial conglomerates.

However, note that to recover the new loans from outstanding loans we need the amortization. Although we do not have new transactions divided between public and private banks, we do have new loans and outstanding loans for firms and consumers in another open base provided by BCB called Time Series Management System -(TSMS) ${ }^{2}$. From this base we got the average amortization for firms and consumers loans as a proportion of outstanding loans, which we denote by $m_{t}$. Thus, the amortization in each market $M_{t i}$ was

\footnotetext{
${ }^{1}$ http://www4.bcb.gov.br/fis/cosif/balancetes.asp

${ }^{2}$ https://www3.bcb.gov.br/sgspub/localizarseries/localizarSeries.do?method=prepararTelaLocalizarSeries
} 
approximated by $M_{t i}=m_{t} S_{i, t-1}$, where $S_{i, t-1}$ is the volume of outstanding loans in period $t$ for a bank $i{ }^{3}$ Since a $S_{i, t-1}$ is given by $S_{i t}=S_{i, t-1}+L_{i t}-M_{t i}$, we recover the new transactions in both credit markets.

$$
L_{i t}=S_{i t}-S_{i, t-1}+M_{t i}
$$

Which we approximate by

$$
L_{i t}=S_{i t}-S_{i, t-1}+m_{t} S_{i, t-1}=S_{i t}-\left(1-m_{t}\right) S_{i, t-1}
$$

Finally, we took the one year interbank market rate from TSMS.

${ }^{3}$ Since the new loans dynamic and policy changes in government-owned banks are coming through the difference in outstanding loans between $t$ and $t-1$ and there is no reason for amortizations considerably differ between public and private banks, this approximation does not harm the evolution of public loans series. 


\section{2 \\ Results}

\subsection{1}

\section{Comparative Static Exercises}

In order to show the model consistency with the economic theory this section presents the main static relations between the model parameters and the loans interest rates for firms and consumers. We do it making isolated changes in: i) the number of private banks, ii) the recovery rates of firms and consumers credit market, iii) the one year interbank rate and iv) the expected default probabilities.

Figures 4.1 (a) and (b) show that a decrease in $20 \%$ in the numbers of private banks (16 to 13$)^{4}$ would lead to a rise of 7.8 p.p. in the annual interest rate for consumers and 1.6 p.p. for firms. The economic intuition behind this result is that, since in our setup banks have a higher market power in consumers credit market, an equivalent decline in competition will lead to a higher increase in interest rate for consumers.

Figures 4.1 (c) and (d) present the effect in interest rates of an equivalent increase in recovery rates on firms and consumers credit market from 0.158 to 0.482 , which is the average recovery rate of a sample composed by Brazilian neighbors Argentina, Chile, Mexico and Colombia. In this exercise we increase the recovery rates in firms and consumers market at the same proportion. This isolated change in the average recovery rate would lead to a decreasing of interest rates in 5.8 p.p. to consumers and 4.2 p.p. to firms.

The result is consistent with the data from Figure 2.4, page 18, which shows the correlation between the average recovery rate and the spread in retail credit market. From the data we that Brazilian spread is much higher than the average one observed in countries with similar recovery rates. What this exercise shows is that even if we just increased the Brazilian recovery rate to a value similar to the one observed in countries with low spread, the Brazilian spread would fall a little but it will continued to be significantly higher than the average of these other countries. The conclusion is that other factor beyond law enforcement are important to understand the huge spread in Brazilian economy, such as risk, cost of funding and banking competition.

In Figures 4.1 (e) and (f) we see that, ceteris paribus, a rise in one interbank market rate from $7.08 \%$ p.y. to $15.26 \%$ p.y. - the same rise observed between January 2012 and January 2017 in Brazilian economy - would lead to

\footnotetext{
${ }^{4}$ Note that there is restriction so that the number of private banks be an integer. As we are reducing the competition in $20 \%$ between private banks, we assume the number of private banks as a continuous variable.
} 
an increase of 10.68 p.p. in the interest rate for consumers and $8.58 \%$ p.p. in interest for firms. Such effect is consistent with the data showed in Figure 2.3 ${ }^{5}$. As a matter of fact, the data shows that the one-year interbank rate has a high correlation with interest rates whether in firms or consumers credit market.

Lastly, Figures 4.1 (g) and 4.1 (h) show the effect on interest rates of changes in default rates. We increased default rates in $50 \%$ in firms and households credit market, a similar rise that took place in Brazil from the 2010 to 2017. By the model, such change would lead to a increase in interest rate of 3.2 p.p. for firms and 6.9 p.p for consumers.

Since interest rates in retail credit market rose in 31.7 p.p. for consumers and 9.38 for firms between January 2012 and January 2017 and no one isolated change had affected interest rates in such order, the comparative static results show that there is no isolated factor capable to explain the rise in Brazilian spreads in this period but, instead, a combination of all of them.

All these results are consistent with the model behavioral functions and, thus, with the economic theory. In the next section we show in what order the model is able to replicate the path of interest rates in Brazilian economy.

${ }^{5}$ Chapter 2. 
Figure 4.1: Comparative Statics Exercises

(a) Change in Competition - Interest Rates for Consumers

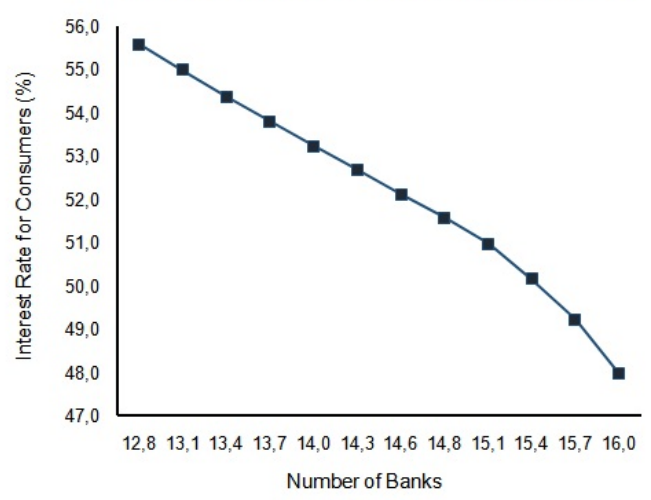

(c) Change in Rec. Rates - Interest Rates for Consumers

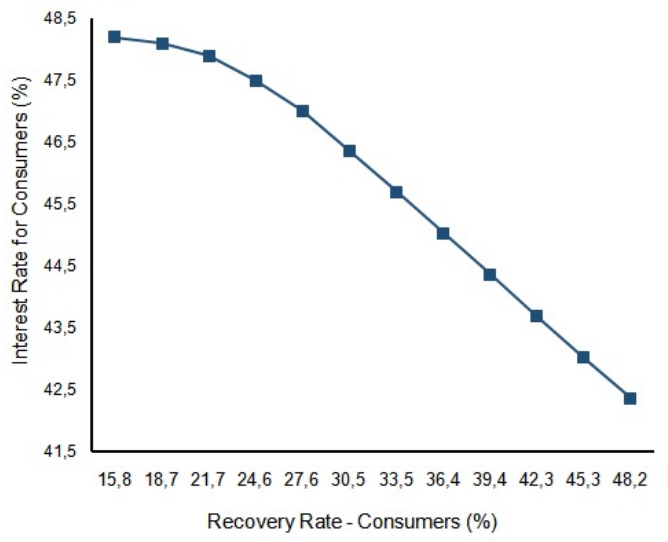

(e) Change in Interbank Rate - Interest Rates for Consumers

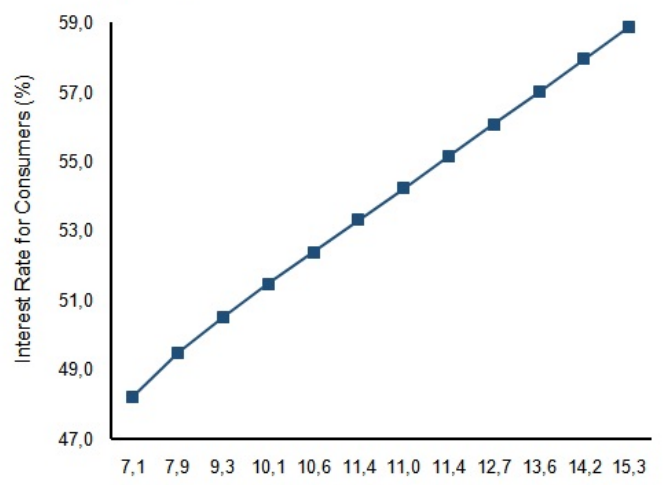

(g) Change in Default Probabilities- Interest Rates for Consumers

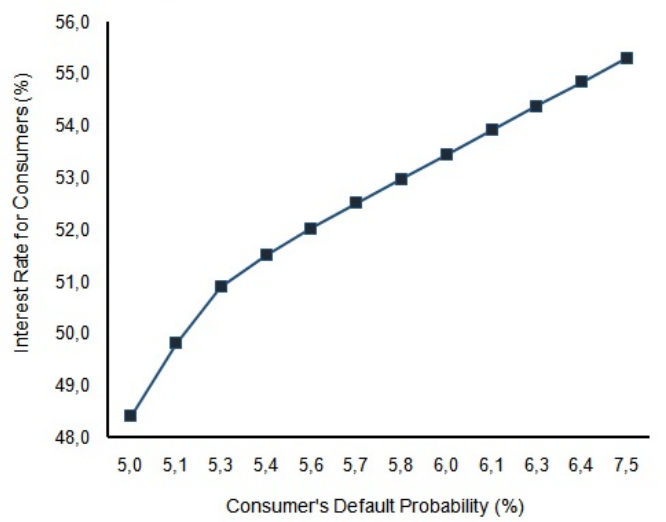

(b) Change in Competition - Interest Rates for Firms

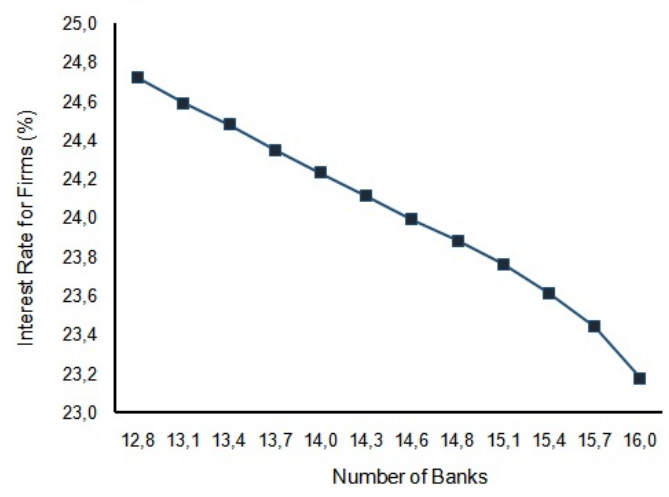

(d) Change in Rec. Rate - Interest Rates for Firms

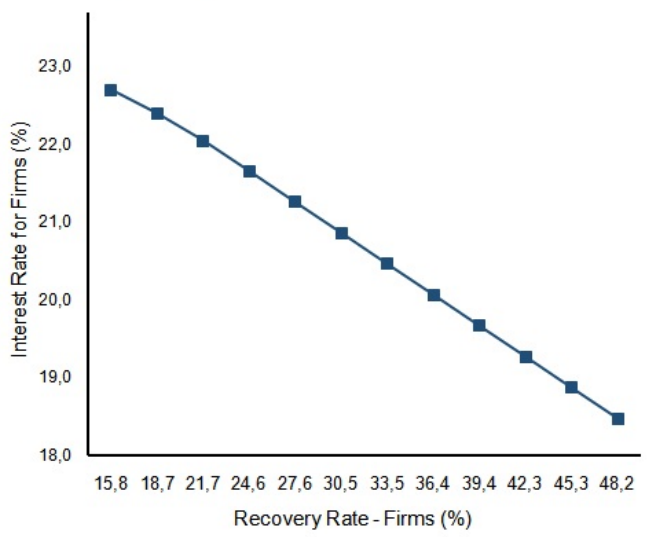

(f) Change in Interbank Rate - Interest Rates for Firms

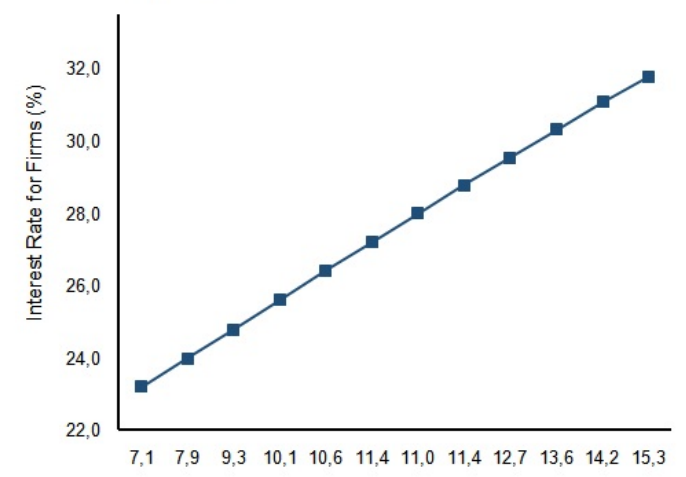

(h) Change in Default Probabilities - Interest Rates for Firms

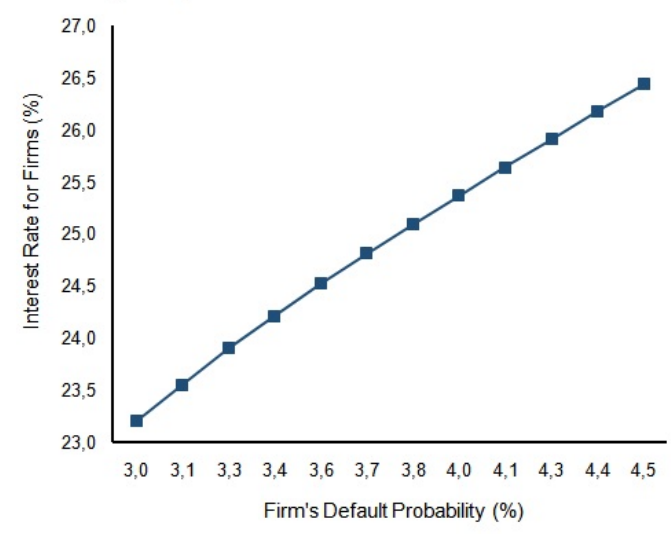




\subsection{2}

\section{Model Fit}

To generate the model fit we first calibrate the model parameters with data from first 2010, which is our starting year in the counterfactual analysis. Then, we change only the parameters of the shock distributive function along the periods in order to capture the risk dynamics in the Brazilian economy. We built the model fit to show in how extension it can replicate the observed dynamics of loans interest rates in Brazilian economy between January 2010 and January 2017.

Figures $4.2 \mathrm{~A}$ and 4.2.B show the interest rate spread from the data and from the model in firms and households credit market. Although the model does not match most of the data, it fits well the long path dynamics of interest rates in both credit markets. It captures the fall in interest rates over 2012 during the forced spread reduction in Rousseff's administration and also the climb in interest rates over 2014 and until the beginning of 2017. Besides, trough different loan demand elasticities and default risks between firms and consumers the model seems to capture the distinguishing features between firms and consumers market.

Figure 4.2: Model Fit

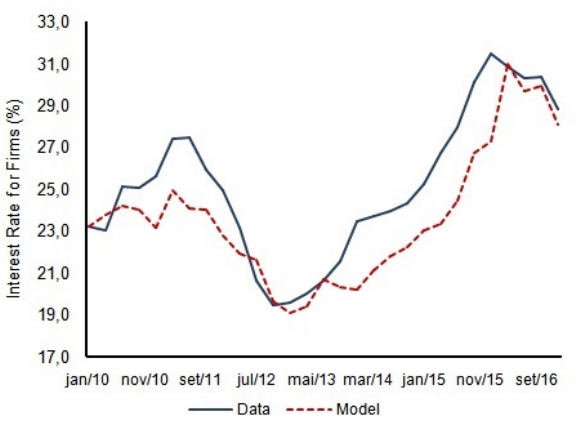

(A)

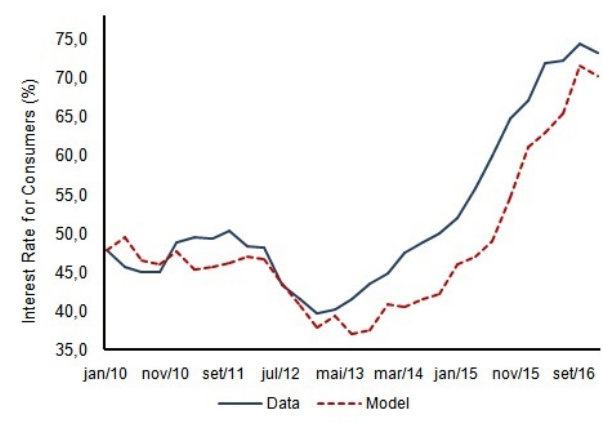

(B)

In relation to the quantities, Figure 4.3 show how the private credit reacts in our model to the exogenous public loans and the other model variables. Since we are working with a Cournot competion model, the private credit supply will come from the best response functions of private banks ${ }^{6}$, which are negatively related to the public loans supply. Therefore, public and private loans will generally present a negative correlation, as we see in Figure 4.3.

${ }^{6}$ Since we solve the model numerically, we can not reach best response as formal functions. 
Figure 4.3: Private Loan's Response

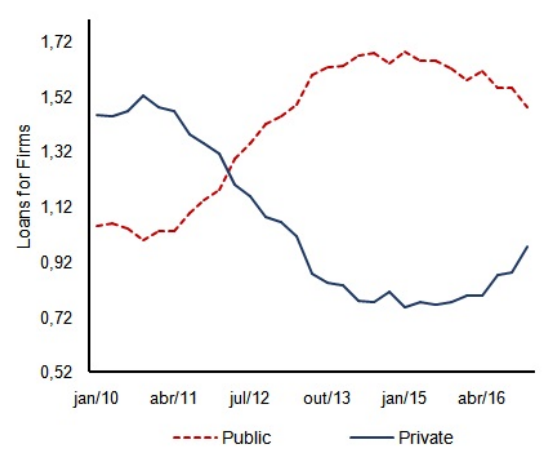

(A)

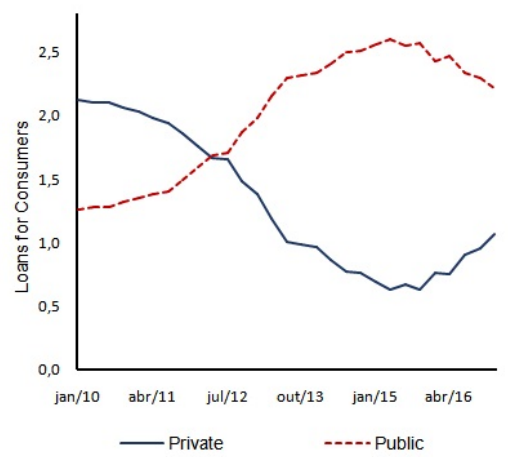

(B)

In next section we analyze the effects of both cyclical and countercyclical public-led credit expansion on interest rates trough counterfactual exercises.

\section{2 .3}

\section{Counterfactual Analysis}

In this thesis, we built two counterfactual scenarios. In the first one, we see what would have been the loans interest rates and spreads if governmentowned banks have not had presented financial fragilities to keep the track of loans expansion rates from previous years. We assume that this would lead to the maintenance of the same countercyclical policy of the period 2012-2015 to the recent economic downturn in Brazil. In the other scenario, we look at what would be the interest rates dynamics if public loans have grown in a more sustainable way between 2012 and 2014 so it did not compromise the capacity of government-owned banks to maintain positive loans expansion rates after the beginning of the economic crisis in Brazil.

Government-owned banks expanded their new lending operations at an average pace of 2.42\% per quarter between March 2012 and March 2015. However, after March 2015 and until January 2017, government-owned banks shrink their credit operations in retail markets at an average pace of $-1.98 \%$ per quarter. What Figures 7.A and 7.B do is to show the interest rate behavior in firms and consumers credit market if government-owned banks had kept the expansion pace of $2.42 \%$ until January 2017. 
Figure 4.4: Keeping the Public Credit Policy Unchanged

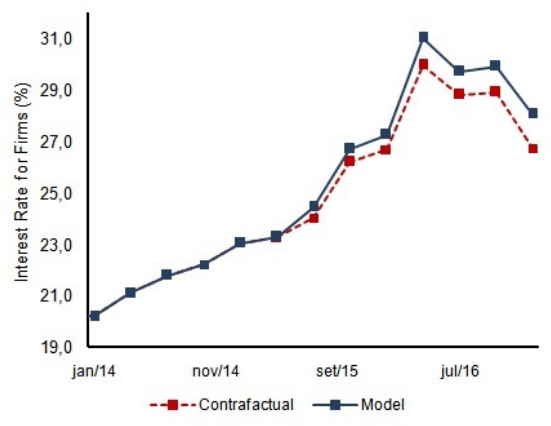

(A)

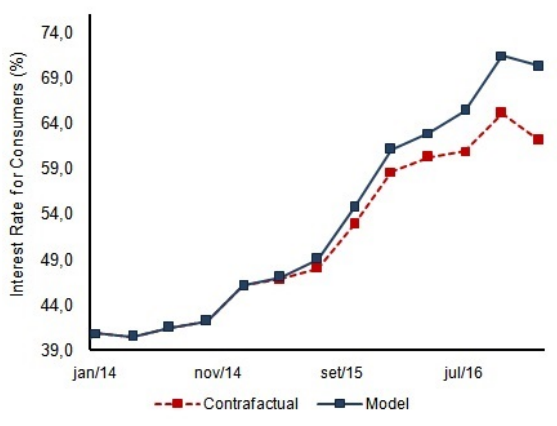

(B)

Our results show that if the credit policy expansion had kept the same rhythm from the previous years the loans interest rate in January 2017 would be $60.03 \%$ y.y. for consumers and $26.23 \%$ y.y. for firms, when model fitted values are $70.25 \%$ and $28.05 \%$ y.y., respectively. Thus, our results show that if public loans had continued to expand at the same path the interest rate would be 10.22 p.p. lower for consumers and 1.82 p.p. lower for firms. As the fitted values show that the interest rates had risen 5.02 p.p. for firms 24.22 p.p.for consumers between March 2015 and January 2017, the change in credit policy was responsible for $26.5 \%$ of the interest rate hike in firms credit market and for $33.7 \%$ of the hike in consumers credit market.

This means that even though interest rates for consumers and firms had risen due to factors not associated with the public credit policy after the first quarter of 2015, such as the interbank rate climb and higher default risks coming from economic downturn, the adoption of a procyclical behavior in public loans supply in a moment of risk leverage is an additional important factor to understand the rise in spreads.

The effect is higher in consumers credit market. Our economic intuition is that since the consumers demand credit is quite more inelastic than the firms one, a supply shock like this would lead to a higher price change for consumers.

The second counterfactual exercise measures what would have been interest rates paths if Rousseff's credit policy had presented a more sustainable growth of new loans transactions so government-banks could keep a macroprudential policy during the recent economic downturn. To do that we considered a $1 \%$ average growth per quarter of new public loans transactions between 2012 and 2017 instead off the $2.42 \%$ one observed between 2012 and 2015. Figures 4.5.A and 4.5.B show the result for firms and consumers market. Figures 4.5.C and 4.5.D show the difference between the model fitted values and the counterfactual values for both markets. 
Figure 4.5: A Sustainable Credit Expansion Policy

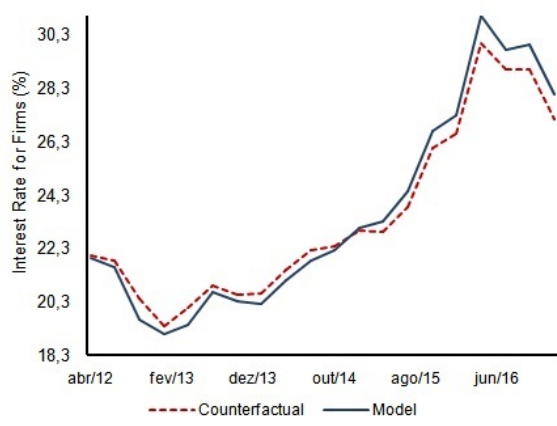

(A)

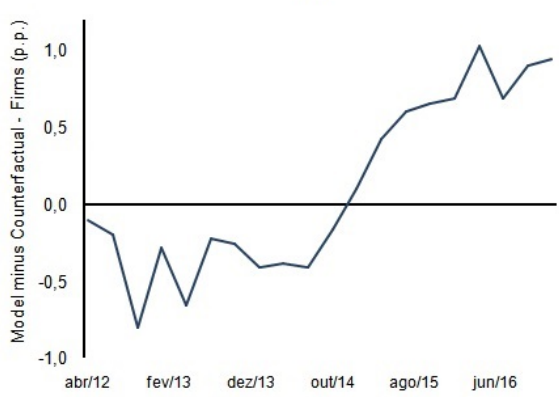

(C)

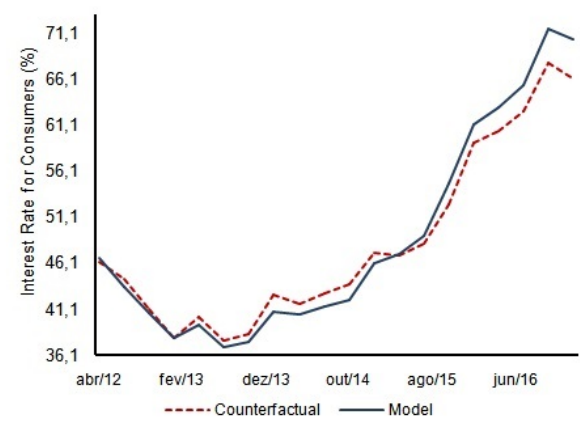

(B)

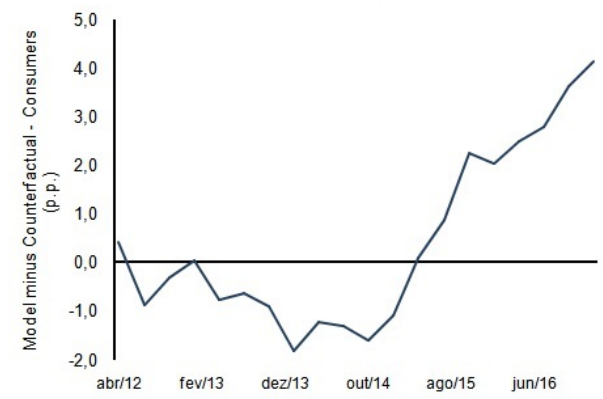

(D)

The results in Figure 4.5.A and 4.5.B show that interest rates would be higher between 2012 and 2015, but lower after that due to the maintenance of a positive average expansion rates in public loans. A more interesting result tough is that the difference between counterfactual interest rates and their fitted values is higher during period of the Brazilian economic crises than in the period between 2012 and 2015, as Figures 4.5.C and 4.5.D. show. Based on this result, a policy of credit expansion would be more effective in reducing bank spreads if it had been concentrated during economic downturns. Therefore, our results indicate that, in order to maximize the potential of the credit macroprudential policy, government-owned banks should perform credit stimulus countercyclically, not cyclically. 


\section{5}

\section{Conclusion}

To understand how government-owned banks affect interest rate spread we adapt Cournot banking competition models in order to consider the countercyclical role played by public loans in the economy. Besides, we propose a split in credit market between firms and consumers to account for the differences in risk and demand elasticities between them.

In this setup, changes credit market variables will affect firm's and consumer's interest rates in different magnitudes since it will depend on the demand elasticities for loans. With the demand for loans being inelastic for consumers and elastic for firms, a loan supply shock - as the one observed in Brazil with the adoption of a procyclical behavior by government-owned banks at the middle of an economic downturn - would lead to a higher rise in loans interest rate for consumers than for firms, as it happened in Brazil between 2015 and 2017. Thus, both the differentiation from the supply side between public and private loans and from the demand side between firms and consumers seems to be important to be considered in order to understand the interest rate spread dynamics in Brazilian economy.

By counterfactual exercises, our results indicate that credit expansion by public banks would be more effective to reduce loans interest rates if it was implemented during the recession period 2015-2017 than during the period of economic expansion 2012-2015. Thus, there would have been a misallocation of public resources in the Rousseff's credit expansion policy per se. Therefore, our results indicate that, in order to maximize the potential of the credit macroprudential policy, government-owned banks should perform credit stimulus countercyclically, not cyclically.

In cases when the credit expansion is not financially sustainable and compromises the public banks capacity to develop countercyclical policies, it could lead to negative shocks in public credit supply just at a moment of economic downturn, when the private credit supply is also shrinking. As a result, this dynamic in public loan supply would intensify the drop in credit operations and the hike in loans spreads commonly observed in economic recessions.

Our results show the change in credit policy in Brazil after the middle of 
2015 was responsible for $26.5 \%$ of the loan interest rate hike for firms and for $33.7 \%$ of the hike for consumers. This means that even though interest rates for consumers and firms had risen due to factors not associated with the public credit policy after the first quarter of 2015, such as the interbank rate climb and higher default risks coming from economic downturn, the adoption of a procyclical behavior in public loans supply in a moment of economic recession intensifies the hike in loans spreads . 


\section{Bibliography}

[1] FREIXAS, X.; ROCHET, J.-C.. Microeconomics of Banking. The MIT Press.

[3] BERTAY, A. C.; KUNT, A. D. ; HUIZINGA, H.. Bank ownership and credit over the business cycle: Is lending by state banks less procyclical? Journal of Banking \& Finance, 50:326-339, 2015.

[4] BARBOSA, K.; ROCHA, B. D. P. ; SALAZAR, F.. Assessing competition in the banking industry: A multi-product approach. Journal of Banking and Finance, 50:340-362, 2015.

[5] MOSHE, K.; BERG, S. A.. Banks as multioutput oligopolies: An empirical evaluation of the retail and corporate banking markets. Journal of Money, Credit and Banking, 30:135-153, 1998.

[6] SHLEIFER, A.; VISHNY, R. W.. Politicians and firms. The Quarterly Journal of Economics, 109:995-1025, 1994.

[7] LA PORTA, R.; FLORENCIO, L.-D.-S. ; ANDREI, S.. Government ownership of banks. The Journal of Finance, 109:995-1025, 2002.

[8] ALLEN, F.; JACKOWICZ, K. ; KOWALEWSKI, O.. The effects of foreign and government ownership on bank lending behavior during a crisis in central and eastern europe. Wharton Financial Institutions Center - Working Paper, No. 13-25, 2013.

[9] COLEMAN, N.; FELER, L.. Bank ownership, lending, and local economic performance during the 2008-2010 financial crisis. Board of Governors of the Federal Reserve System - International Finance Discussion Papers, 2014.

[10] BIGNOTTO, F. G.; RODRIGUES, E. A. S.. Fatores de risco e o spread bancário no brasil. Relatório de Economia Bancária e Crédito, 2005. Banco Central do Brasil, 2009.

[11] AFANASIEFF, T. S.; LHACER, P. M. V. ; NAKANE, M. I.. The determinants of bank interest spread in brazil. XXIX Encontro Nacional de Economia. Salvador, 2010. 
[12] CARDOSO, M.; AZeVEdo, P. F. D. ; BARBOSA, K.. Poder de mercado e nível de competição no mercado de empréstimo brasileiro. Insper Working Paper, 2017.

[13] NAKANE, M. I.; ALENCAR, L. S.. Bank competition, agency costs and the performance of the monetary policy. Working Paper Series - Banco Central do Brasil, 2004.

[14] COELHO, C. A.; DE MELLO, J. M. P.; GARCIA, M. ; RIGOBON, R.. A method for identifying aggregate credit supply and demand parameters using heteroskedascity: An application for brazil. Working Paper, 2017.

[15] RIGOBON, R.. Identification through heteroskedasticity. Review of Economics and Statistics, 85(4), 2013.

[16] DIÁZ-GIMÉNEZ, J.; PRESCOTT, E.; FITZGERALD, T. ; AlVAREZ, F.. Banking in computable general equilibrium economies. Journal of Economic Dynamics and Control, 16:533-559, 1992.

[17] MAS-COLELL, A.; WHINSTON, M. D. ; GREEN, J. R.. Microeconomic theory. Oxford University Press, 1995. 